EFFiciert

\title{
Factors Affecting the Use of Public Transportation in Semarang City
}

\author{
Destin Witari Tazaruwah ${ }^{1}$, Dyah Maya Nihayah ${ }^{2}$ \\ Jurusan Ekonomi Pembangunan, Fakultas Ekonomi, Universitas Negeri Semarang \\ Permalink/DOI: https://doi.org/10.15294/efficient.v2i3.35867
}

Received: Juny 2019 ; Accepted: September 2019 ; Published: December 2019

\begin{abstract}
Economic activities require the transfer of goods and services to be effective and efficient with transportation. The number of motorized vehicles at this time is not comparable to the place of mobility, causing traffic jams. Efforts to reduce congestion are implemented in the city of Semarang through public transportation called BRT Trans Semarang. However, these efforts have not been successful because the number of motorized vehicles has increased after the BRT, which means that the public transportation in Semarang has not been able to overcome traffic jams and facilitate the people of Semarang City. Therefore, it is necessary to know the factors that influence the community in using the BRT Trans Semarang. This study aims to determine the factors that influence the decision to use the BRT Trans Semarang and its surplus. This study used a questionnaire to 10o respondents. Distribution of questionnaires with non probability sampling methods. The dependent variable of this study is the decision to use BRT Trans Semarang. While the independent variables are travel time, accessibility to bus stops, private vehicle ownership, and the presence of online transportation. Besides the willingness to pay variable to calculate the surplus. The analysis tool used is binary logistic regression.The results showed that the accessibility variables to stops, private vehicle ownership, and the presence of online transportation had an influence on decisions in the use of the BRT Trans Semarang. Consumer surplus from BRT Trans Semarang users from the tariff of Rp. 86,000 .
\end{abstract}

Keywords: BRT Trans Semarang, Waktu Tempuh, kenyamanan ke Halte, Kepemilikan Kendaraan Pribadi, Transportasi, Surplus Konsumen

\begin{abstract}
Abstrak
Kegiatan ekonomi berupa perpindahan barang dan jasa akan lebih efektif dan efisien dengan transportasi. Kondisi saat ini jumlah kendaraan bermotor tidak sebanding dengan tempat mobilitasnya, sehingga terjadilah kemacetan. Upaya untuk mengurangi kemacetan melalui transportasi publik berupa BRT Trans Semarang belum sesuai dengan harapan karena masih banyaknya pengguna kendaraan pribadi. Oleh karena itu penelitian ini bertujuan untuk mengetahui faktor - faktor yang mempengaruhi masyarakat dalam penggunaan BRT Trans Semarang dan surplusnya. Penelitian ini menggunakan kuesioner yang disebarkan kepada 100 responden. Penyebaran kuesioner dilakukan dengan metode non probability sampling. Variabel dependen penelitian ini adalah keputusan penggunaan BRT Trans Semarang. Sedangkan variabel independen nya adalah waktu tempuh, aksesibilitas ke halte, kepemilikan kendaraan pribadi, dan adanya transportasi online. Selain itu variabel willingness to pay untuk menghitung surplusnya. Adapun alat analisis yang digunakan adalah regresi logistik biner. Hasil penelitian menunjukkan bahwa variabel aksesibilitas ke halte, kepemilikan kendaraan pribadi, dan adanya transportasi online memiliki pengaruh terhadap keputusan dalam penggunaan BRT Trans Semarang. Surplus konsumen pengguna BRT Trans Semarang dari tarif sebesar Rp 86.0oo.
\end{abstract}

Kata Kunci: BRT Trans Semarang, Waktu Tempuh, Aksesibilitas ke Halte, Kepemilikan Kendaraan Pribadi, Transportasi, Surplus Konsumen

How to Cite: Tazaruwah, D., \& Nihayah, D. (2019). Factors Affecting the Use of Public Transportation in Semarang City. Efficient: Indonesian Journal of Development Economics, 2(3), $478-494$. https://doi.org/10.15294/efficient.v2i3.35867

(C) 2019 Semarang State University. All rights reserved

\footnotetext{
Alamat Korespondensi :

Alamat: Gedung L2 Lantai 2 FE Unnes

Kampus Sekaran, Gunungpati, Semarang, 50229

E-mail : efficientjournal@gmail.com
}

ISSN 2655-6197 


\section{INTRODUCTION}

Economic activity is inseparable from transportation. Transportation has a great influence on the activities of individuals, society, economic development, and sociopolitical status of a country (MG. Endang Sri Utari \& Dyah Maya Nihayah, 2016). The movement of goods and services will be faster with the presence of transportation, so that with the existence of transportation will facilitate access and distribution of goods and services from one region to another. The number of motorized transportation in Indonesia continues to increase, while the road as a place of mobility remains, resulting in traffic congestion mainly in urban areas.
Semarang City is one of the most congested cities in Indonesia. Semarang is included as the 9th most congestion city in Indonesia with a congestion rate of 37 hours a year. Semarang as the capital of Central Java Province is on the Kedung Sepur line (Kendal, Demak, Ungaran, Semarang, and Purwodadi), which are goods and services trade routes. In addition, the city of Semarang is also a center for economic, educational and industrial activity, so many immigrants live in it. The population is 4,310 people / $\mathrm{km}$ and the total area is $373.7 \mathrm{~km} 2$ (BPS Kota Semarang). The number of vehicles in the city of Semarang is as follows:

Table 1. Number of Motor Vehicles in Semarang City 2013-2017

\begin{tabular}{|c|c|c|c|c|c|c|}
\hline \multirow{2}{*}{ Year } & \multicolumn{2}{|c|}{ Private Vehicle } & \multirow{2}{*}{ Amount (unit) } & \multicolumn{2}{|c|}{ Public Vehicle } & \multirow{2}{*}{ Amount (unit) } \\
\hline & Wheel 2 \& 3 & 4 Wheels & & Small & Large & \\
\hline 2013 & 854.043 & 141.735 & $995 \cdot 778$ & 3.490 & 2.063 & $5 \cdot 553$ \\
\hline 2014 & 991.602 & 172.538 & 1.164 .140 & 3.617 & 2.331 & 5.948 \\
\hline 2015 & $1.172 .5^{21}$ & $197 \cdot 774$ & 1.370 .295 & 4.259 & 2.534 & 6.793 \\
\hline 2016 & 1.387 .600 & 238.152 & $1.625 \cdot 75^{2}$ & 4.697 & 2.803 & $7 \cdot 500$ \\
\hline 2017 & 1.532 .679 & 448.529 & 1.981 .208 & 5.153 & 3.072 & 8.207 \\
\hline
\end{tabular}

Source : BPPD Central Java Province, 2019

Based on table 1. it is known that the number of motorized vehicles in the city of Semarang shows an increase every year. The increase in the number of motorized vehicles was dominated by private vehicles both 2 \& 3 wheels and 4 wheels. Public vehicles also experienced an increase but the number and increase were not as large as private vehicles. The increase in private vehicles every year increases between $14-18 \%$, while public transportation is only $6-12 \%$. From this data shows that people tend to choose to use private vehicles rather than public vehicles. Increasing the use of motorized vehicles in addition to having an impact on congestion will also cause a slowdown in the distribution of goods, waste of fuel, pollution, and so forth. Moreover, motor vehicle mobility is dominated in areas where there is a lot of economic activity.

The level of congestion in the city of Semarang is quite high, so that the city of Semarang is in the 9 most congested cities in Indonesia. Semarang City is an urban area that 
is the center of economic activity ranging government areas there will be a lot from markets, industries, offices, and government centers. This area will be a lot of activities that require transportation. The market will bring together buyers and sellers to trade around the economy. In industrial estates there will be lots of in and out of large vehicles for raw and finished goods, and in office and of human activity to work. These activities will become easier if transportation is smooth, and vice versa if there are problems in the form of transportation congestion it will only interfere. Based on Semarang City Transportation Department data, there are 15 roads in Semarang City with high density. The road sections are as follows:

Table 2. Levels of Road Density in Semarang City Based on Road Service Level

\begin{tabular}{clcccc}
\hline No & \multicolumn{1}{c}{ Roads } & Volume & Capacity & V / C Ratio & Category \\
\hline 1 & Jl.Pandanaran & 5720,43 & 6696,43 & 0,85 & E \\
2 & Jl. Bigjen Soediarto & 6089,17 & 6576,47 & 0,93 & E \\
3 & Jl. Teuku Umar & 6026,91 & 6406,20 & 0,94 & E \\
4 & Jl. Wahidin & 5200,88 & 5911 & 0,88 & E \\
5 & Jl. MT. Haryono & 5526,91 & 6284,52 & 0,88 & $\mathrm{E}$ \\
6 & Jl. Pahlawan & 4539,37 & 6234,45 & 0,73 & $\mathrm{D}$ \\
7 & Jl. Sultan Agung & 4143,35 & 4930 & 0,83 & $\mathrm{D}$ \\
8 & Jl. Kaligawe & 6819,35 & 9541,54 & 0,71 & $\mathrm{D}$ \\
9 & Jl. Soekarno Hatta & 1690,78 & 2283,06 & 0,74 & $\mathrm{D}$ \\
10 & Jl. Tandean & 2323,53 & 3340,44 & 0,75 & $\mathrm{D}$ \\
11 & Jl. Ahmad Yani & 4321,51 & 5564,80 & 0,78 & $\mathrm{D}$ \\
12 & Jl. Sriwijaya & 4249,78 & 5437,20 & 0,78 & $\mathrm{D}$ \\
13 & Jl. Imam Bonjol & 3136,76 & 5082,60 & 0,62 & $\mathrm{C}$ \\
14 & Jl. Woltermonginsidi & 2926,75 & 5354,40 & 0,55 & $\mathrm{C}$ \\
15 & Jl. M.H Thamrin & 2636,65 & 4658,33 & 0,57 & $\mathrm{C}$ \\
\hline
\end{tabular}

Source: Semarang City Transportation Agency, 2019

\section{Category Description:}

A $=$ Free flow, low volume, high

(o.o- o.19) speed

B = The current is stable and

(o.20-0.44) starts speed limitation

$\mathrm{C}=$ The current is stable, driving

(o.45-0.69) comfort is down, and movement is restricted

$\mathrm{D}=$ Current approaches

(o.70-0.84) unstable, speed starts to be interrupted by road conditions.

$\mathrm{E}=\mathrm{A}$ traffic jam has occurred $(0.85-1.00)$

In table 2. illustrates the level of road density in the city of Semarang which is indicated by the Volume / Capacity (V / C) ratio. $\mathrm{V} / \mathrm{C}$ ratio is the ratio between the volume of motor vehicles with the capacity of 
the road contained in an area. $\mathrm{V} / \mathrm{C}$ ratio value which is getting closer to 1 , means that the level of traffic density is getting higher. While the $\mathrm{V} / \mathrm{C}$ ratio is getting closer to o, the traffic density is getting lower. The high or low value of $\mathrm{V} / \mathrm{C}$ ratio shows the higher the level of road service. A high $\mathrm{V} / \mathrm{C}$ ratio means lower road services, and conversely a lower $\mathrm{V} / \mathrm{C}$ ratio of higher service. There are 5 roads in the city of Semarang that are classified as E category, which is a road that is indicated by a traffic jam. The 5 roads are Jl. Pandanaran, Jl.Brigjen Soediarto, Jl. Teuku Umar, Jl. Wahidin, and Jl. M.T Haryono. The road section is the main road section in which all types of transportation use this road section. This pathway is also an important pathway for the distribution of goods and services as well as community mobility in activities.

Semarang City with its vision that is "Semarang City of Great Trade and Services Towards a More Prosperous Community". Based on this vision, it can be interpreted that the City of Semarang will realize a metropolitan city that is environmentally friendly, reliable, and advanced in the trade of goods and services, with adequate infrastructure support and remains an area that is conducive to improving the welfare of its citizens with political, security, social, economic support, and culture.

Semarang City Government's efforts in realizing its vision have provided various modes of public transportation such as BRT, public bus, and public transportation. The provision of this mode of transportation is also equipped with facilities and infrastructure such as bus stops, terminals, paved roads, street lights, and complete and adequate traffic signs to support the existence of such public transportation. The existence of public transportation along with its infrastructure is expected to be able to divert or replace the use of private vehicles to public vehicles, so that it can reduce the number of use of private vehicles and reduce congestion and facilitate the flow of traffic in the city of Semarang. But in reality the number of private vehicle users still dominates in the City of Semarang. Besides private vehicles that are not from the city of Semarang that participate in urbanization of people from various regions also increase the number of private vehicles on the streets. Therefore, the government continues to strive to overcome these problems by planning for sustainable transportation as applied to developed countries in managing their transportation systems.

The Semarang City Government to overcome congestion and facilitate urban transportation starting in 2010 provides public transportation in the form of mass transportation. The purpose of mass transportation is to realize efficiency, energy savings, and low-cost urban transportation services (Pujiati, et al, 2018). Mass transportation in Semarang is in the form of Bus Rapid Transit (BRT), which is fast bus with a capacity of 40 - 80 passengers. BRT Trans Semarang operates in the city of Semarang with a predetermined line. This BRT public transportation is an adoption from Bogota, Colombia. The existence of this multi-mode transit system has succeeded in reducing the level of congestion in Bogota, Colombia. The BRT in Bogota is called Trans Milenio. The existence of Trans Milenio is able to reduce the level of congestion and make travel faster. The hope is that the BRT in Semarang City can be 
one of the solutions in minimizing traffic congestion in the city of Semarang. The BRT Trans Semarang Travel Route has been well integrated and has the same fare for both short and long distances. The number of BRT Trans Semarangs operating in Semarang City is as follows:

Table 3. Number of BRT Trans Semarang Operating per Corridor in $2010-2018$

\begin{tabular}{lllllllll}
\hline \multirow{8}{*}{ Year } & \multicolumn{7}{c}{ Corridor } \\
\cline { 2 - 7 } & I & II & III & IV & V & VI & VII & \\
\hline 2010 & 20 & - & - & - & - & - & - & 20 \\
2011 & 16 & - & - & - & - & - & - & 16 \\
2012 & 14 & 17 & - & - & - & - & - & 31 \\
2013 & 16 & 20 & - & 5 & - & - & - & 41 \\
2014 & 20 & 24 & 10 & 18 & - & - & - & 72 \\
2015 & 20 & 24 & 10 & 18 & - & - & - & 72 \\
2016 & 20 & 24 & 10 & 18 & - & - & - & 72 \\
2017 & 24 & 24 & 16 & 24 & 14 & 14 & - & 116 \\
2018 & 25 & 34 & 16 & 22 & 16 & 16 & 13 & 142 \\
\hline S011
\end{tabular}

Source: Semarang City Transportation Agency, 2019

Based on table 3. it can be seen that the number of the BRT Trans Semarang fleet and its corridors is increasing every year. This is intended so that the community can be accommodated in using public transportation. There are 7 BRT travel corridors, corridor I, namely the Mangkang - Penggaron route. Corridor II, namely the Terboyo - Sisemut route. Corridor III, the Tanjung Mas - Akpol line which began operating in November 2014. Corridor IV passes the Cangkringan line A.Yani Airport which was inaugurated earlier than Corridor III in December 2013, but only 5 BRT units. Then Corridor V on the Matesih PRPP line was inaugurated along corridor VI of the UNNES - UNDIP Pathway in March 2017. In 2018 a corridor VII with the Terboyo Genuk - Bangetayu - Artery Soekarno Hatta Balaikota lines was added. The increasing number of BRT fleets is balanced by the increasing number of people who use it. The data is as follows:

Table 4. Number of BRT Trans Semarang Passengers in $2010-2018$

\begin{tabular}{llll}
\hline Year & $\begin{array}{l}\text { General } \\
\text { Passenger }\end{array}$ & $\begin{array}{l}\text { Student } \\
\text { Passenger }\end{array}$ & $\begin{array}{l}\text { Total } \\
\text { Passenger }\end{array}$ \\
\hline 2010 & 260.416 & 108.910 & 369.326 \\
2011 & 1.195 .436 & 483.106 & 1.678 .542 \\
2012 & 1.431 .811 & 528.389 & 1.960 .200 \\
2013 & 3.118 .690 & 702.455 & 3.821 .145 \\
2014 & 4.228 .661 & 1.603 .789 & 5.832 .450 \\
2015 & 5.931 .699 & 3.821 .145 & 8.023 .869 \\
2016 & 5.851 .425 & 5.832 .450 & 7.725 .490 \\
2017 & 6.541 .592 & 8.023 .869 & 9.125 .472 \\
2018 & 7.066 .264 & 7.725 .490 & 10.210 .296 \\
\hline
\end{tabular}

Source: Semarang City Transportation Agency, 2019

Based on Table 4. the number of BRT Trans Semarang passengers since it began operating in 2010 has also increased the number of passengers each year. In the first year of operating BRT with 20 BRT units the number of passengers was 369,326 passengers a year. Then in 2011 with 16 BRT units the number of passengers also increased to $1,678,542$ passengers. Furthermore, the number of passengers is increasing from year to year balanced by the number of BRT and its travel corridors. In 2018 with 7 corridors, the number of passengers will reach 10,210,296 with 142 BRT units in operation. 
In Semarang City still dominates private transportation users. This is evidenced by the number of private vehicles that continues to increase from year to year even though there are public vehicles in the form of BRT Trans Semarang. The number of private vehicles in the city of Semarang in 2017 reached 1,981,208 units. The number of BRT Trans Semarang vehicles also increased to 142 units with 7 travel corridors. From this figure it can be concluded that the number of private vehicles and public vehicles is directly proportional to the increase, so the number of vehicles on the road actually increases. Government efforts in providing public transportation have not been responded well by the community, this is certainly influenced by factors that cause people not to use public transportation that can not be separated from consumer choices.

Associated with the theory of choosing modes of transportation by Tamin (2000), that in choosing a mode of transportation is influenced by several things such as the existence of transportation options, comfort \& safety, travel routes, and travel time, as well as the level of service. BRT Trans Semarang public transportation has fulfilled several factors. The comfort and safety of BRT Trans Semarang users has been guaranteed by the government with the facilities on the bus, besides that it also provides complaints services for passengers who are less comfortable. Travel routes have provided 7 routes that have been used, which route is a route that is often used for community activities. The level of service has also been carried out in accordance with procedures, because officers at the BRT are recruited directly by the BLU BRT Trans Semarang. Based on the theory of transportation mode selection, people should be willing to use the BRT Trans Semarang because what has been considered has been fulfilled.

The choice of transportation mode as one of the factors that influence the use of transportation according to Tamin (2000) is the cause of the large number of people who choose to use vehicles other than public transportation, such as private vehicle ownership in the form of motorbikes or cars, and recently the existence of online transportation. Therefore these two variables are used as variables in this study. This is supported by research conducted by Kambuaya (2019) that private vehicle ownership has an influence on demand for urban transport services in the city of Manado. In addition, the results of Hendryanti's research (2018), about $88 \%$ of passengers choose to switch from conventional public transportation to online transportation, while the remaining $12 \%$ of passengers continue to use conventional public transportation.

As one of the factors that also affects the use of transportation, travel time is related to flows in the road network (Tamin; 200o). The more vehicles there are on the road, the road will be congested and the current in the road network will be slow and this will affect all transportation users. The existence of the BRT Trans Semarang as mass public transportation should be able to accommodate the people of Semarang City and reduce the use of other transportation that can meet the current road network, but the community still continues to use their private vehicles. Therefore travel time is used as a variable in this study to determine whether travel time is still a consideration of the community in using transportation. A similar study conducted by Kambuaya (2019) 
states that travel time has an influence on the use of public transportation, while according to Winarno and Manullang (2017) no effect.

According to John Black in Tamin (2000), accessibility is a measure of the comfort or ease of achieving the location and its relationship with each other, easily or difficult the location is achieved through transportation. Accessibility here includes the comfort factor in the use of transportation. Accessibility to the BRT shelter has been placed in areas that are much needed by the community in its activities, but people still use their private vehicles. Therefore accessibility to bus stops is used as a variable to find out the factors that influence the use of the BRT Trans Semarang. BRT Trans Semarang Public Transportation with a tariff of Rp 3500 for public passengers and Rp 1000 for students.

\section{METHOD}

This research is a quantitative descriptive study with a cross section research design. The data used are primary data obtained through the results of distributing questionnaires to respondents directly. The questionnaire in this study was a closed question with two choices namely "Yes" and "No". This firm choice was chosen to be used so that the answers given by respondents were clear. Before the questionnaire was distributed, the validity and reliability were tested. Validity test is done using Pearson Product Moment Correlation and Reliability Test with Kuder Richardson Test (KR-21).

Then the results of the data from the questionnaire were processed using Binary Logistic Regression analysis and calculation of consumer surpluses by calculating the difference between respondents' Willingness to Pay (WTP) with the applicable Ability to Pay (ATP). The sample used was as many as 100 respondents calculated using the Slovin formula and the non-probability sampling technique of Hapadzard type or Convenience Sampling, namely sampling by taking only the units found (Asra and Prasetyo; 2016). The dependent variable used is the decision to use public transportation. Then there are four independent variables namely travel time, accessibility to bus stops, private vehicle ownership, and the presence of online transportation. As an amplifier in inviting the public to use public transportation, this study also calculated the consumer surplus in the use of the BRT Trans Semarang by calculating the difference in the WTP and ATP BRT Trans Semarang rates.

The analytical method used in this study is the logistic regression model. The type of logistic regression used in this study is binary logistic regression. This binary logistic regression is used because there are only 2 possible response variables. The logistic regression analysis method has several advantages, namely (1) Logistic regression does not have an assumption of normality over the predictor variables used in the model. This means that the variables in this study do not have to be normally distributed, linear, or have the same variant. (2) The predictor variables used can be a mixture of continuous, discrete, and dichotomous variables.

The logistic regression analysis technique no longer requires the normality test and the classic assumption test on the independent variable (Ghozali, 2009). Logistic regression also ignores the problem of heteroscedasticity, 
meaning that the dependent variable does not require homocedasticity for each independent variable (Gujarati, 2012). Besides logistic regression is very useful to use if the distribution of responses to the dependent variable is expected to be nonlinear with one or more independent variables.

Binary logistic regression does not directly model the dependent variable $(\mathrm{Y})$ with the independent variable $(\mathrm{X})$, but through the transformation of the dependent variable into a logit variable which is the natural log of the odd ratio. So that natural logarithm values can be determined which can be formulated in the equation as follows:

$$
\begin{aligned}
\operatorname{Ln}\left(\frac{P}{1-p}\right)= & \beta 0+\beta 1 x 1+\beta 1 x 2+\beta 3 x 3 \\
& +\beta 4 x 4 \ldots \ldots \ldots \ldots \ldots \ldots \ldots \ldots
\end{aligned}
$$

Information :

$\mathrm{P} \quad$ : It is likely that $\mathrm{Y}=1$

B : Regression Coefficient

$\mathrm{X}_{1} \quad$ : Travel time

$\mathrm{X}_{2} \quad$ : Accessibility

$\mathrm{X}_{3} \quad$ : Ownership of private vehicles

$\mathrm{X}_{4}$ : Use of online transportation

\section{RESULTS AND DISCUSSION}

This research was conducted to determine the effect of travel time, accessibility, ownership of motorized vehicles, and the presence of online transportation on decisions in the use of public transportation (BRT Trans Semarang). Binary logistic regression (binary logistic regression) is an analysis tool used to determine this effect. The analysis was carried out with the help of the SPPS program.

Respondents in this study were residents of Semarang City. The selection of respondents was carried out randomly. Respondents in this study were 100 people according to the sample calculation using the Slovin formula. Of the 100 respondents used as samples in this study there were various ages using the BRT Trans Semarang. Therefore, grouping of the age of the passengers is carried out so that it can be seen at what age the average BRT Trans Semarang user is. Most respondents were passengers aged $20-24$ years as many as $14 \%$ or 14 people. Then the ages of $15-19$ years and ages $25-29$ are the same, each at $13 \%$ or 13 people. Ages $30-34$ years as many as $12 \%$ or 12 people. Ages 35 - 39 years and $40-44$ years each at $11 \%$ intervals or 11 people. Age 45-49 years as many as $9 \%$ or 9 people. Ages $50-54$ years as many as 8 percent or 8 people. Age 55 - 59 years as many as $3 \%$ or 3 people, and aged $60-64$ by $2 \%$ or 2 people.

Based on data obtained from distributing questionnaires to 100 respondents there were male and female passengers. Respondents in this study were dominated by female passengers, namely $79 \%$ or 79 people. While the remaining $21 \%$ or 21 people are male respondents. Based on the latest education level, respondents in this study were dominated by respondents with the highest level of education being $54 \%$ or 54 respondents, then $\mathrm{S}_{1}$ as many as $23 \%$ or 23 respondents. Respondents with the most recent education at SMP / MTS and SD amounted to $8 \%$ or 8 people. Diploma respondents are $6 \%$ or 6 people, whereas postgraduate $\mathrm{S}_{2}$ and $\mathrm{S}_{3}$ respondents are only $1 \%$ or 1 respondent only.

Based on the type of work of 100 respondents $49 \%$ or 49 people consisted of student respondents, $26 \%$ or 26 private respondents. Then $11 \%$ or 11 respondents have 
jobs as traders. Only $5 \%$ of respondents have jobs as laborers or 5 people, while there are $3 \%$ civil servants or 3 people. The remaining $11 \%$ or 11 people said they had other jobs. Other jobs mentioned are doctors, seamen, non civil servant teachers, and housewives.

The different itineraries of each respondent in this study are grouped into 5 categories that are often carried out by the community. As for research based on 100 respondents following the number of respondents based on the purpose of his trip when using the BRT Trans Semarang, there were $34 \%$ respondents or 34 people used BRT for the purpose of school trips, then $29 \%$ or 29 people worked. The purpose of vacation travel as much as $10 \%$ or 10 people and $13 \%$ or 13 people for shopping trips, and $14 \%$ or 14 people for other travel destinations. The other trip is to return home, to the hospital, and go to the station.

There are several tests conducted to determine the effect of the independent variables on the dependent variable, namely (1) Assessing Model Fit consists of overall model fit test, Determination Coefficient Test (Negelkerke's R Square, and Model Goodness of Fit), (2) Test Partial (Wald Test), (3) Calculation of Consumer Surplus The following are the results of the test:

Table 5. Model Fit Test

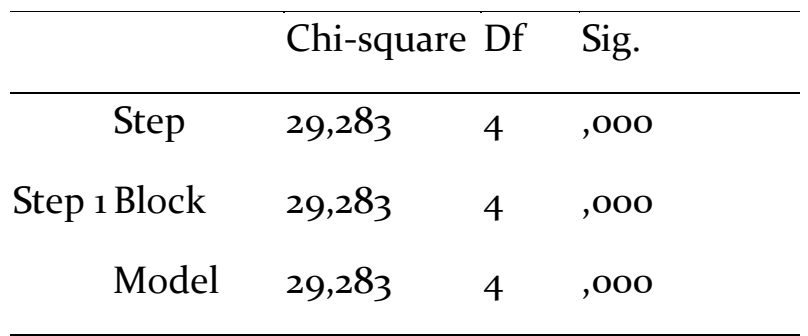

Source: Primary data processed, 2019
Based on the table above shows that the chi-square value of 29.283. The chi-square value of 29.283 was the difference of $-2 \mathrm{log}$ likelihood before the independent variable entered the model $(131,791)$ minus -2 log likelihood after the independent variable entered the model $(102,508)$. The chi-square value in table $\mathrm{df} 4$ with a significance level of 0.05 that is equal to 9,488 . The results of the calculated chi-square value $(29,283)>$ chisquare table value $(9,488)$, it can be interpreted that the addition of an independent variable gives a real influence on the model, or the model can be declared Fit.

These results can be interpreted that the decision to use the BRT Trans Semarang can be predicted from the variables of travel time, accessibility, ownership of motorized vehicles, and the presence of online transportation.

The Coefficient of Determination test using the Nagelkerke R Square value can be interpreted as the $\mathrm{R}$ Square value in multiple regression. Values close to o (zero) indicate that the ability of independent variables in explaining the dependent variable is very limited. While the value is close to 1 (one), it indicates that the independent variables provide almost all the information needed to predict the dependent variable.

Nagelkerke R Square value in this study amounted to $0.347(34.7 \%)$. This shows that the independent variable in this study was only able to explain the dependent variable by $34.7 \%$, while the remaining $65.3 \%$ was explained by other variables outside the variables in this study.

Other variables outside this study are various possibilities as in the study of Borhan, et.al (2014) states that the desire to use public 
transportation is influenced by the quality of service, attitudes, and behavioral intentions. Good and comfortable service quality will make passengers prefer using public transportation. Attitudes of friendly and helpful service providers will make passengers feel safe using public transportation. In addition, the behavioral intentions of the passengers themselves in the selection of transportation use to meet their needs. Another possibility, as in the study of Surung (2014), is that income and transportation costs also affect the use of public transportation.

The Model Feasibility Test is based on the results of the Hosmer and Lemeshow Test with a significance value of $0.353>0.05$, which means that the model is able to predict the value of its observations. It can be said that the model is acceptable because it matches the observational data.

Table 6. Parsial Test (Uji Wald)

\begin{tabular}{llllll}
\hline & & B & df & Sig. & $\operatorname{Exp}(B)$ \\
\hline \multirow{4}{*}{$\begin{array}{llllll}\text { Step } \\
1^{\text {a }}\end{array}$} & x2(1) &,- 746 & 1 &, 194 &, 474 \\
& x3(1) & 1,177 & 1 &, 029 & 3,245 \\
& x4(1) & $-1,470$ & 1 &, 007 &, 230 \\
& Constant & 2,865 & 1 &, 000 & 17,555 \\
\hline
\end{tabular}

Source: Primary data processed, 2019

Based on the results of data processing in table 6. logistic regression equations can be made as follows:

$$
\begin{aligned}
\operatorname{Ln}(p /(1-p))= & 2,865-746 X_{1}+1,177 X_{2}- \\
& 1,470 X_{3}-2,279 X_{3}-e \\
\operatorname{Ln}(p /(1-p))= & 2,865-746 \text { (Travel Time) } \\
& +1,177 \quad \text { (Accessibility) - } \\
& 1,470 \quad \text { (Personal Vehicle } \\
& \text { Ownership) }-2,279 \text { (Trans. } \\
& \text { Online) }+\mathrm{e}
\end{aligned}
$$

The parameter used in this study is to compare the significance value with a significance level of $5 \%$ or 0.05 . Based on the above Wald test results it can be concluded that the travel time variable has a coefficient value of -0.746 which means it has a negative influence meaning. If the travel time is getting shorter, the probability of people using BRT Trans Semarang is increasing, and vice versa.

The probability or tendency of the community to use or not use the BRT Trans Semarang of 0.474 seen from the value of Exp (B) means that the community who decides to use the BRT Trans Semarang Public Transport (Code 1) considers the travel time 0.474 times greater than the community don't use BRT Trans Semarang (Code o). The estimated binary logistic regression has a significance level of 0.194 . This shows that the significance value of $0.194>$ the real level of 0.05 , it can be interpreted that the travel time variable has no effect on community decisions in deciding to use or not use the BRT Trans Semarang.

The significance value of the travel time variable is 0.194 , the value is greater than the significance level of $5 \%$ or 0.05 . These results can be interpreted that the travel time variable does not affect the decision in the use of the BRT Trans Semarang. This is not in accordance with the theory of Tamin (2000) which states that the factors that influence the choice of mode based on the characteristics of transportation mode facilities are travel time. Generally someone in choosing to use transportation will think of travel time, because transportation is intended to speed up the journey, but not the results of this study.

The results do not affect the variable travel time on the decision to use or not use the BRT Trans Semarang, when viewed from 
the phenomenon of research conducted using the BRT Trans Semarang does not consider travel time. Judging from the results of questions number 7 and 8 on the research instrument the results show that the BRT Trans Semarang travel time is not faster than other vehicles and the journey is not fast to the destination or includes a long time. However, the decision to use the BRT Trans Semarang in the results of questions number 1 to 5 states that they agree or choose to use the BRT Trans Semarang. It can be concluded that the public in using the BRT Trans Semarang does not care about the travel time needed, but considers other things such as low prices, facilities, and services provided.

As in the theory of consumer choice states that consumers will think rationally in using transportation. Consumers tend to use goods / services that they consider to be more profitable for them. As is the case in this case if consumers consider the BRT Trans Semarang travel time is long, but consumers will continue to use it because consumers think rationally low prices, AC bus facilities, and good service primarily prioritizing disabled passengers, parents, and pregnant women have a place sit down so that consumers are comfortable using BRT Trans Semarang. Whereas consumers who consider that the BRT Trans Semarang is a transportation that takes a fast time but does not use it, consumers pay attention to other things such as convenience and practicality to get the transportation. In addition there are also some people who have a physically weak / drunk vehicle choosing not to use public transportation even though in terms of tariffs, facilities, and travel time in accordance with consumer expectations.

The results do not affect the variable travel time to the use of the BRT Trans Semarang is similar to the study conducted by Kambuaya (2019). The study states that the travel time of urban transportation does not affect the demand for urban transport services. Travel time has no effect on the use of public transportation because people are less concerned about the amount of time spent traveling. There are some areas where there is no other transportation that reaches the area, so people continue to use it. The absence of transportation options causes consumers not to pay attention to travel time to use city transportation. Possible risks in using it have been considered and if the travel time feels long consumers can get around by leaving early, so it does not interfere with productivity.

The accessibility variable has a coefficient of 1.177 which means it has a positive influence. If accessibility to bus stops is easy, then the probability of people using the BRT Trans Semarang will also be even greater, and vice versa. The probability or tendency of the community to use or not use the BRT Trans Semarang can be seen in the value of Exp (B), which is 3,245 means that people who decide to use the BRT Trans Semarang Public Transport (Code 1) consider the accessibility to stops as large as 3,245 times compared to people who don't use BRT Trans Semarang (Code o). The estimated binary logistic regression has a significance level of 0.029 . This shows that the significance value of 0.029 $<0.05$, it can be interpreted that the accessibility variable influences community 
decisions in deciding whether or not to use the BRT Trans Semarang.

The significance value of the accessibility variable to the bus stop is 0.029 which is smaller than the significance level of $5 \%$ or o.05. Because the significance value is less than 0.05 , it can be interpreted that the accessibility variable to the bus stop influences the decision to use the BRT Trans Semarang. The odds ratio value of Accessibility to Stop is seen at Exp (B) of 3,245 which means that the probability of respondents who decide to use BRT Trans Semarang is 3.245 times greater for respondents who have accessibility to easy stops compared to the difficult ones.

Accessibility here is a convenience to the bus stop which is assessed from the measurement of the distance to the BRT shelter from the residence and the respondent's destination. Based on the theory of Tamin (200o), states that movement or travel is a person's consideration in using modes of transportation. Especially in Indonesia, which has geographic islands islands, lowlands and highlands causing the need for diverse modes of transportation. BRT Trans Semarang is a mass public transportation that is specifically designated as urban transportation. The coefficient value of the test results is 1.177 with a positive sign $(+)$ indicating that the accessibility to the bus stop with the decision to use the BRT Trans Semarang has a positive or unidirectional relationship. When accessibility to bus stops is easy, respondents will decide to use the BRT Trans Semarang and vice versa when accessibility to bus stops is difficult then respondents will decide not to use the BRT Trans Semarang.
Based on the phenomenon of the results of the research that has been done it is known that accessibility to bus stops is a consideration in the use of the BRT Trans Semarang. From questions 9 through 11 on the instrument the results show that although the location of the bus stop is not close to the house, easy access to the bus stop respondents will use the BRT Trans Semarang. Respondents also assumed that the location of the bus stops was appropriate to their needs. The effect of accessibility to shelters on the use of BRT is in accordance with research conducted by (Surung, 2014) which revealed that accessibility to shelters influences the decision to use BRT. Users of BRT Trans Semarang according to Surung's research are people who cannot drive private vehicles, and people who do not use BRT Trans Semarang even though the access is near the bus stop but the destination is not bypassed by BRT, so the community will choose effectively to get to their destination.

The variable ownership of private vehicles has a coefficient of $-1,470$ which means it has a negative influence. If the community has a private vehicle, then the probability of the community using the BRT Trans Semarang will also be smaller, and vice versa. The probability or tendency of the community to use or not use the BRT Trans Semarang can be seen in the value of $\operatorname{Exp}(B)$, which is equal to o.230 meaning that people who decide to use the BRT Trans Semarang public transport (Code 1) more consider ownership of a private vehicle by 0.230 times greater compared to people who do not use BRT Trans Semarang (Code o). The estimation of binary logistic regression has a significance level of 0.007 . This shows that the significance value of 0.007 
$<0.05$, it can be interpreted that the accessibility variable influences the community's decision to decide whether to use or not use the BRT Trans Semarang.

The coefficient value of -1.470 with a negative sign (-) indicates that there is a negative or inverse relationship between private vehicle ownership and the decision to use the BRT Trans Semarang. Respondents who have private vehicles tend not to use BRT Trans Semarang, while respondents who do not have private vehicles will tend to use BRT Trans Semarang. Ownership of private vehicles will make the respondent's needs for transportation fulfilled so they don't need other vehicles. This result is in accordance with the mode selection theory proposed by Tamin (2000) that the availability or ownership of private vehicles is included as a factor which is believed to greatly influence the mode selection. The higher the vehicle ownership the smaller the dependence on public transport.

Ownership of private vehicles both cars and motorbikes tends to indicate that the user will travel using his own vehicle. The use of private vehicles will affect the use of public transportation. As the results of research Chuen, et al. (2014), One of the main reasons for the low use of public transportation is the dependence on using private vehicles. This is very rational because private vehicles are considered more effective than using public transportation.

Based on the phenomena of the research that has been done it can be seen that the average community who owns a private vehicle does not want to replace their personal vehicle use with the BRT Trans Semarang. This result is seen from the consumers' answers to the questions on questionnaires number 5 and number 12. In question number 5 states the willingness to use the BRT Trans Semarang to replace the use of private vehicles. Whereas on number 12 states ownership of a private vehicle. Of the 100 respondents used as $54 \%$ or 54 respondents who have private vehicles. Whereas those who are willing to replace the use of private vehicles to the BRT Trans Semarang are only $15 \%$ or 15 respondents who have a vehicle and are willing to replace their personal vehicle use with the BRT Trans Semarang.

This study is different from research conducted by Jain (2016) which states that private transportation users are willing to switch to using Personal Rapid Transit (PRT). $69.5 \%$ of bicycle users, 38.8 car users, and $17.2 \%$ two-wheeled motorbike users, and pedestrians $23.4 \%$ are willing to switch to using Personal Rapid Transit (PRT).

The influence of private vehicle ownership on the use of public transportation is in accordance with previous research conducted by Kambuaya (2019). The results of the previous study stated that the ownership of private vehicles negatively influences the demand for city transportation services, which means that when respondents have private vehicles, the use of city transportation will decrease. The decline in the use of city transportation as investigated by Kambuaya (2019) in Pangkep Regency is because people prefer to use their private vehicles and they consider using private vehicles to be far more effective.

The variable of online transportation has a coefficient of $-2,279$ which means it has a 
negative influence. If the community prefers to use online transportation, then the probability of the community using the BRT Trans Semarang will also be smaller, and vice versa. The probability or tendency of the community to use or not use the BRT Trans Semarang can be seen in the value of $\operatorname{Exp}(B)$, which is 0.102 , meaning that people who decide to use the BRT Trans Semarang Public Transport (Code 1) more consider the existence of online transportation of 0.102 times greater compared to people who don't use BRT Trans Semarang (Code o). The estimated binary logistic regression has a significance level of o,ooo. This shows that the significance value of o,ooo $<0.05$, it can be interpreted that the accessibility variable to the bus stop affects the community's decision to decide whether to use or not use the BRT Trans Semarang.

The coefficient value of $-\mathbf{2 , 2 7 9}$ with a negative sign (-) indicates that there is a negative or inverse relationship between online transportation and the decision to use the BRT Trans Semarang. When there is online transportation, the respondents decide to use online transportation and not to use the BRT Trans Semarang. Whereas when there is no online transportation, respondents will use the BRT Trans Semarang. The presence and absence of online transportation is certainly determined by the availability of media such as Android, online transportation applications, and data packages for internet connections.

The existence of online transportation is a consideration in the use of public transportation. Online transportation as substitute goods which both are modes of transportation used to meet the needs of transit from one place to another. The negative or inverse relationship between online transportation and the use of the BRT Trans Semarang is in accordance with research conducted by Hendryanti (2018) which states that $88.86 \%$ of conventional public transport users switch to online transportation. The transfer of the use of conventional public transportation to online transportation is because respondents consider that online transportation is more practical in ordering and paying.

Based on the phenomenon of the results of research that has been done, it is known that the existence of online transportation is a consideration in the use of the BRT Trans Semarang. From questions 15 through 19 on the instrument the results show that $97 \%$ or 97 respondents already knew and $77 \%$ of respondents had used online transportation. In addition, $66 \%$ of respondents also felt that using online transportation was more practical. Prospective passengers only need to order transportation from home and will be picked up and delivered to the destination location. And payments can be made in cash or non-cash. That convenience makes online transportation a consideration in the decision to use public transportation.

Surplus or benefits in using BRT Trans Semarang can be seen from what consumers get more compared to using other transportation. As urban public transportation for the purpose of public welfare, of course, what is provided is not for personal gain but for the common good. Trans Semarang BRT as public transportation in serving the people of Semarang City has several superior facilities compared to other mass public transportation. The service products are, (1) a very cheap transportation service system for users of public transportation in the city of Semarang, 
(2) a cheap price, because it is subsidized $50 \%$ by the government of the city of Semarang and the route far near the passenger is enough to pay one ticket, ( 3) Convenient because using an $\mathrm{AC}$ bus with reliable passenger waiting time, (4) Safe because BRT service users get a sense of security from all disturbances.

It is hoped that the more facilities provided by the Trans Semarang BRT can make the people of Semarang use this BRT and replace the use of their private vehicles. So that what has been given by the government in an effort to provide public transportation in the city of Semarang can be accepted by the community and useful as the purpose. Therefore this research will calculate the consumer surplus when viewed from the side of Willingness to Pay (WTP) and Ability to Pay (ATP), so that the ability to pay consumers and consumer benefits apart from subsidies provided by the government can be known.

The calculation of the Consumer Surplus is done by subtracting the willingness to pay (WTP) at the applicable rate (ATP). Willingness to Pay in this study there are 3 rates that respondents are willing to spend, namely Rp. 4,000, Rp. 5,000, and Rp. 3,500 (not surplus). While the applicable tariff or ATP is IDR 3,500. The calculations are as follows:

Table 7. Consumer Surplus for General Passengers

\begin{tabular}{|c|c|}
\hline Cost Rp 4.000 & Cost Rp 5.000 \\
\hline$=\mathrm{Rp} \quad 4.000-\mathrm{Rp}$ & $=\mathrm{Rp} \quad 5.000-\mathrm{Rp}$ \\
\hline $3.500=\operatorname{Rp} 5.00$ & $3.500=\operatorname{Rp} 1.500$ \\
\hline WTP Rp 4.000 & WTP Rp 5.000 \\
\hline$=\mathrm{Rp} 500 \quad \mathrm{x} 22$ & $=\operatorname{Rp} 1.500 \quad x \quad 28$ \\
\hline Person $=$ Rp 11.000 & Person $=$ Rp 42.000 \\
\hline
\end{tabular}

Source: Data processed, 2019
From the above calculation it can be seen that the consumer surplus per passenger with a WTP of Rp 4,00o when using $1 x$ is $R p 500$ (five hundred rupiah). Then if calculated based on the total respondents as general passengers is $\mathrm{Rp}$. 11,00o (eleven thousand rupiah). The consumer surplus per passenger with a WTP of Rp. 5,000 when using one time is Rp. 1,500 (five hundred rupiah). Then if calculated based on total respondents as general passengers is Rp 42,00o (forty two thousand thousand rupiah).

The Consumer Surplus for Student Passengers is carried out by reducing the willingness to pay (WTP) at the applicable rate (ATP). Willingness to pay consumers to use the BRT Trans Semarang or Willingness to Pay (WTP) in this study, there are 2 tariffs that respondents are willing to spend, namely $\mathrm{Rp}$ 2,00o and still Rp 1,00o (not surplus). While the applicable tariff or ATP is Rp. 1,ooo. The calculations are as follows:

Table 8. Consumer Surplus for Student Passengers

\begin{tabular}{l}
\hline Cost Rp 1.000 \\
\hline$=$ Rp $2.000-\mathrm{Rp} 1.000$ \\
$=\mathrm{Rp} 1.000$ \\
\hline WTP Rp 2.000 \\
\hline$=$ Rp 1.000 x 33 Orang \\
$=$ Rp 33.000
\end{tabular}

Source: Data processed, 2019

From the above calculation it can be seen that the consumer surplus per passenger with a WTP of Rp. 2,00o when using $1 x$ is Rp. 1,00o (one thousand rupiah). Then if calculated based on the total respondents as public passengers the total surplus of respondents 
who use the BRT Trans Semarang as a public passenger is Rp. 33,000 (thirty-three thousand rupiah).

Indirectly consumers have felt the benefits of using the BRT Trans Semarang. Judging from the low fares for both short and long distances as long as they do not leave the BRT bus stop, they only need to pay one ticket, namely Rp. 3,500 (three thousand five hundred rupiah) for general passengers and Rp. 1,00o (one thousand rupiah) for student passengers. This causes consumers to not have to pay more and repeat. BRT Trans Semarang public transportation when compared to other public transportation such as public transportation, public buses, and taxis are very much different indeed. Starting from the rates, facilities, and services. BRT Trans Semarang as Semarang City's public transportation indeed aims to provide services that are cheap, safe, comfortable, cultured and affordable to all walks of life. Therefore, by using the BRT Trans Semarang, of course, every consumer will get a surplus both in terms of tariffs, facilities, and services. It also can reduce the use of private transportation, so it can reduce traffic density and reduce congestion in the city of Semarang.

\section{CONCLUSION}

Based on the results of research and discussion that has been found that the variables that influence the decision to use the BRT Trans Semarang are accessibility to bus stops, private vehicle ownership, and the presence of online transportation. The accessibility variable to the bus stop has a positive influence on the decision to use the BRT, which is when accessibility to the bus stop is easy then the community will decide to use the BRT Trans Semarang. And vice versa if the accessibility to the bus stops is difficult then the community decides not to use the BRT Trans Semarang. Variable Ownership of Private Vehicles and the existence of Online Transportation has a negative influence on the use of BRT, which when the community has a private vehicle and there is online transportation accompanied by supporting media, the community decides not to use the BRT Trans Semarang and decides to use their own private vehicle or transportation existing online. While the travel time variable does not affect the decision to use the BRT Trans Semarang, this means that in using the community it does not take into account the length of the trip, but rather by other factors such as cheap prices or convenience.

The advantage of using the BRT Trans Semarang is based on the calculation of the consumer surplus by setting aside the ability and willingness to pay (WTP) with the applicable tariff (ATP), the results show that people are more fortunate to use the BRT Trans Semarangcompared to other public vehicles. In addition, in terms of tariffs imposed by society, they still have the ability and willingness to be above the tariffs imposed.

\section{REFERENCES}

Asra, Abuzar dan Achmad, Prasetyo. (2016). Sampling in Survey Research. Jakarta : PT Raja Grafindo Persada

BPPD. (2018). Number of Semarang City Motor Vehicles 2013 - 2017. Central Java Regional Revenue Management Agency

BPS. (2016). Semarang City Area. https://semarangkota.bps.go.id/statictable/2015/o 4/23/4/luas-wilayah-kota-semarang.html. Badan Pusat Statistik Kota Semarang 
Borhan, Muhamad N. et al. (2014). Predicting the Use of Public Transportation: A Case Study from Putrajaya, Malaysia. The Scientific World Journal Research Article Volume 2014Article ID 784145. Malaysia : Hindawi Publishing Corporation

Chuen, O.C., Mohamed R.K., \& Sumiani Y. (2014). Mode Choice between Private and Public Transport in Klang Valley, Malaysia. The Scientific World Journal. Malaysia : Hindawi Publishing Corporation

Dinas Perhubungan Kota Semarang. (2019). Number of BRT Trans Semarang fleet operating per corridor in 2010-2018. Semarang. Dinas Perhubungan Kota Semarang

Dinas Perhubungan Kota Semarang. (2019). Number of BRT Trans Semarang Passengers in 2010-2018. Semarang. Dinas Perhubungan Kota Semarang.

Dinas Perhubungan Kota Semarang. (2019). Road Density Level in Semarang City Based on Road Service Level. Semarang : Dinas Perhubungan Kota Semarang

Gozali,Imam. (2009). Advanced Multivariate Analysis with SPSS Program. Semarang: Diponegoro University Publisher Agency

Gujarati, D. N. (2012). Basics of Econometrics Book 2 (Issue 5). Jakarta : Salemba Empat.

Hendryanti dan Ayunditya, Alberta jessica. (2018). The Influence of Online Transportation Towards Public Transportation in the Special Region of Yogyakarta. Thesis. Yogyakarta : Universitas Atma Jaya Yogyakarta

Jain, et al. (2016). Demand Estimation of Personal Rapid Transit (PRT) Using Stated Preference Technique and Binary Logit Models. Journal of Transport Literature, 10(2), 5-9,Apr 2016. Brazil : ITPS Manaus Brazil ISSN 2238-1031
Kambuaya, Agus Elia, Masinambow,Vecky \& Sumual,jacline. 2019. Analysis of Variables (Factors) That Influence Demand for City Transport Services in Malalayang District, Manado City. Periodical Scientific Journal Efficiency Volume 19, No. o1 of 2019. Manado: Department of Development Economics Faculty of Economics and Business. Universitas Sam Ratulangi

MG.Endang Sri Utari \& Dyah Maya Nihayah. (2016). Analysis of Travel Demand for Users of Executive Railway Services in Semarang - Jakarta Route (Argo Muria and Argo Sindoro Railroad Study).Economic Depelopment Analysis Journal, Volume 5 No. 3. Hal 314-322 Semarang : Universitas Negeri Semarang

Pujiati, A.,Bowo P., \& Nihayah, D. (2018). The Urban Sustainability Index in Urban Aglomeration. JEJAK : Jurnal Ekonomi \& Kebijakan, 11 (2), 294 305. Doi:https://doi.org/10.15294/jejak.v11i2.16052

Surung, ni putu diah dan Arka, Sudarsana. (2014). Factors That Influence the Use of "Trans Multipurpose" Public Transportation Services (Case Study of Udayana University Students). Journal of Applied Quantitative Economics Vol 7 No.1 February 2014. Bali: Department of Development Economics Faculty of Economics and Business Universitas Udayana

Tamin, Ofyar Z. (200o). Transportation Planning and Modeling Second Edition. Bandung : Institut Teknologi Bandung

Winarno, B., \& Manullang, O.R. (2018). Determinants of Use of Public Transportation in Pati City. Workshop Volume 20 Number 1, 75-86. Semarang: UNDIP Planalogy Publishing Bureau. 